exhaustively studied in $F_{2}$ families from self-fertilization. By this method no clear indication of linkage was found. From back-crosses (453 plants from heterozygous females, and 418 plants from heterozygous males) 47 per cent of crossing-over was obtained ${ }^{1}$. Hence, in a recent summary of our knowledge of linkage in Pisum, these two genes are placed in different chromosomes ${ }^{2}$.

Chromosome 1 of the normal structural type has undergone interchange with three other chromosomes in types 2,3 and 6 . When these three types are crossed with the normal, and the $F_{1}$ structural hybrids are also heterozygous for $R$ and $A$, the $F_{2}$ progenies show either linkage between $R$ and $A$, with about 30 per cent crossing-over (in hybrids $1 \times 2$ and $1 \times 6)$, or linkage of both genes with the gametic sterility by which the position of the translocation is indicated (in hybrid $1 \times 3$ ). The evidence is derived, in hybrid $1 \times 2$, from back-cross ratios, and in hybrids $1 \times 3$ and $1 \times 6^{3}$ from $F_{2}$ ratios. Hence it follows that the genes $R$ and $A$ lie in the one chromosome of the normal type common to all three associations of chromosomes in the hybrids at meiosis, that is. in No. 1 of Mrs. Sansome's list.

That linkage may be shown in structural hybrids but not in homozygous types may be expected from the slight reduction in chiasma frequency observed by Sansome $e^{4}$ and Sutton ${ }^{5}$ and characteristic of such hybrids. Further, the incidence of gametic sterility in relation to other genes serves as a new locus. Hence the genetical analysis of structural hybrids may be a more effective method of studying the distribution of the genes than the analysis of structurally homozygous types. Caroline Pellew.

John Innes Horticultural Institution, London, S.W.19.

Dec. 11.

'Pellew, ('., Z. Zucht. A, Pflanzenzücht., 17, 90 (1931).

2 Winge, Ö., C.R. Trav. Lab. Carlsb., (Ser. Physiol., 15), 21 (1936).

S Sansome, F. W., and E. R., unpublished.

4 Sansome, E. R., Cytologia, 3, 200 (1932)

s. Sntton, E., Ann. Bot., 49, 689 (1935).

\section{Technique of the Painting Process in the Cave Temple at Sittannavasal}

As an extension of my studies ${ }^{1}$ on Indian paintings, I have had recently an opportunity of investigating the technique of the painting process adopted in the cave temple at Sittannavasal in the Pudukottah State, South India, situated at a distance of about 42 miles by road from Tanjore. This cave temple is rery small, being about 24 feet long, 12 feet wide and 11 feet high. The interior was at one time fully painted, but at present the paintings are visible only on the ceilings, the capitals and the upper parts of the pillars. These paintings, which can be assigned to the time of the great Pallava king, Mahendravarman I (c. 600-625 A.D. $)^{2}$, represent the best specimens of Jain mural paintings of the classical or Ajanta school extant in India, and there can be no doubt about their æsthetic merit or high importance from the point of view of history.

From a study of the painted stucco, it is clear that the technique adopted in the execution of these paintings is one of fresco-secco or painting in lime medium on plaster. The stucco is composed of the Rinzaffo or rough coat of lime plaster with a fine lime wash thereon. The lime wash was probably given while the plaster was still wet. The thickness of the stucco depends on the nature of the surface of the wall and the ceilings, and varies from $1.9 \mathrm{~mm}$. to $3.4 \mathrm{~mm}$. and in certain places it goes up to about $8.9 \mathrm{~mm}$.

The results of analysis of the stucco (excluding the Jime-wash) were as follows:

Moisture
Silica, $\mathrm{SiO}_{2}$
Iron and alumina, $\mathrm{V}_{2} \mathrm{O}_{3}+\mathrm{Al}_{2} \mathrm{O}_{3}$
Carbon Dioxide, $\left(\mathrm{O}_{2}\right.$
Lime, $\mathrm{CaO}$
Magnesia, MgO
Sulphuric anhydride, $\mathrm{SO}_{3}$
Loss on ignition
Undetermined (mostly alkalis)

\begin{tabular}{c} 
Per cent \\
$2 \cdot 14$ \\
$48 \cdot 91$ \\
$3 \cdot 98$ \\
$18 \cdot 07$ \\
$24 \cdot 37$ \\
$0 \cdot 35$ \\
$0 \cdot 11$ \\
$0 \cdot 65$ \\
$1 \cdot 39$ \\
\hline $99 \cdot 97$ \\
\hline
\end{tabular}

The only inert material used with the lime is sand.

So far as pigments are concerned, lime has been used for the white, carbon for black, yellow and red ochres for yellow and red, lapis lazuli or ultramarine for blue, terre verte for green and a mixture of the last two for bluish-green.

Full details of the investigation will be published in the Technical Studies of the Fogg Art Museum of Harvard University.

Chemical Laboratory,

\section{S. Paramasivan.}

Government Museum,

Madras.

Dec. 19

'NATURE, 137, 867 (1936).

${ }^{2}$ Mehta, N. C., "Studies in Indian Painting" (Taraporevala, Bombay, 1926, p. 9).

\section{Raman Spectrum of Benzene Vapour}

MUCH interest is attached to the structure of benzene, and a series of important papers ${ }^{1}$ dealing with this subject and based mainly on Raman, infra-red and emission spectra have recently appeared from University College, London. In this connexion it is very desirable to possess a knowledge of the Raman spectrum of benzene vapour, but no data are yet

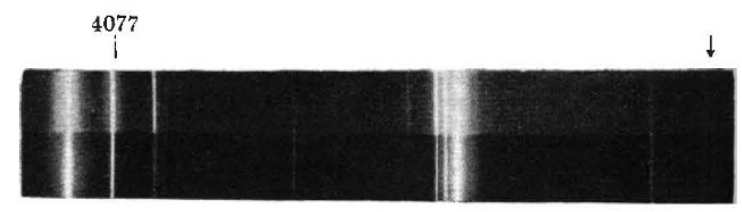

Fig. 1.

RAMAN SPECTRUM OF BENZENE VAPOtR (ABOVE), LIQLID (BFLOW).

available. Fig. l (upper spectrum) shows the Raman spectrum of benzene vapour obtained by us at a pressure of $15 \mathrm{~atm}$. and a temperature of $200^{\circ} \mathrm{C}$.; the lower spectrum is the Raman spectrum of the liquid taken alongside, keeping the conditions regard. ing slit width, etc., unaltered but reducing the time of exposure. Fig. 2, $a$ and $b$, are photometric records of the wings accompanying the $\lambda 4077$ and $\lambda 4046$ lines respectively in the vapour. Fig. 2, $c$, is the record of the wing accompanying the line $\lambda 4046$ in the liquid taken under identical conditions. Among other notable features, the following changes which take place as we pass from the liquid to the vapour are of special significance.

The principal Raman line 992 shows no shift. 3061 shows a definite shift (see arrow in Fig. 1) and has a value of 3069 in the vapour. 3047 has either completely disappeared or has been considerably 